DOI: https://doi.org/10.32839/2304-5809/2021-7-95-24

УДК 336.228

Голютяк-Пенкальска М.В.

Ягеллонський Університет м. Кракова

\title{
ЗЛОВЖИВАННЯ ПОДАТКОВИХ ОРГАНІВ В ПРАВОВІДНОСИНАХ З ПЛАТНИКАМИ ПОДАТКІВ
}

Анотація. У роботі ретельно досліджено проблему зловживань правом у сфері оподаткування податковими органами. Сутнісна причина неправомірної поведінки органів криеться в переважанні користі й упевненості в тому, що вони можуть отримати певний зиск від задоволення неправомірних інтересів при зловживанні своїми правами, над потенційними негативними наслідками такого зловживання. Таким чином, зловживання посадовими особами податкових органів своїми повноваженнями призводить до заподіяння шкоди правам і законним інтересам платників податків. На жаль, Податковий кодекс України не передбачає жодних чітких процедур захисту прав сумлінних платників податків, що дає службовим особам податкового органу необмежені можливості для зловживань правом. У статті детально описуються різноманітні види незаконних дій податкових органів у сфері оподаткування та досліджуються причини таких зловживань. У цій роботі також виокремлено групу зловживань, пов'язаних з автоматизацією податкових правовідносин, запровадженням системи електронного адміністрування ПДВ.

Ключові слова: зловживання податкових органів, неправомірна поведінка податкових органів, захист прав платників податків, типи недобросовісних дій податкових органів, зловживання, пов'язані 3 автоматизацією податкових правовідносин, класифікація зловживань податкових органів.

Holutiak-Pekalska Marija Jagiellonian University in Cracow

\section{ABUSE OF TAX AUTHORITIES IN LEGAL RELATIONS WITH TAXPAYERS}

Summary. This article investigates the problem of abuse of rights in the field of taxation by tax authorities. The essential reason for the misconduct of the authorities lies in the predominance of benefits and confidence that they can gain some benefit from the satisfaction of unlawful interests in the abuse of their rights, over the potential negative consequences of such abuse. Officials, abusing their relations with taxpayers, do not fulfill their obligations under Art. 21 of the Tax Code of Ukraine, in particular: to comply with the Constitution of Ukraine and act exclusively in accordance with the Tax Code of Ukraine, other laws of Ukraine and other regulations, to ensure effective work and tasks of controlling bodies in accordance with their powers and to prevent violations of the rights and legally protected interests of taxpayers. Unfortunately the Tax Code of Ukraine does not provide clear procedures for the protection of the rights of honest taxpayers, which gives tax authorities officials unlimited opportunities for abuse of rights. The article describes in detail the types of unfair actions of tax authorities in the field of taxation and the causes of such abuses. According to the general concept of abuse of rights in tax relations, abuse is most often combined with dishonest behavior and two main types of dishonest actions in the field of taxation. The first one is an abuse of subjective rights arising from the provisions of private law, aimed at circumventing the provisions of tax law - is inherent in taxpayers who do not comply with the requirements of tax law. The second one is an abuse of direct subjective tax rights - such abuse is inherent in the tax authorities. This article investigates the second type of unfair actions of tax authorities, inter alia: abuses related to the calculation and payment of mandatory payments by the taxpayer, as well as the receipt of budget reimbursement, abuses related to the implementation of the control function, abuses related to the provision of tax revenues. This article also identifies a group of abuses related to the automation of tax relations and the introduction of an electronic VAT administration system.

Keywords: abuse of tax authorities, illegal behavior of tax authorities, protection of taxpayers' rights, types of unfair actions of tax authorities, abuses related to automation of tax relations, classification of abuses of tax authorities.

Постановка проблеми. Актуально

1 в Україні, на жаль, дії податкових органів дуже часто не здійснюються в межах правового поля, що, у свою чергу, призводить до заподіяння шкоди правам і законним інтересам платників податків. В статті приводяться приклади протизаконних дій податкових органів та детально описано типи недобросовісної поведінки органів у сорері оподаткування а також проаналізовано причини таких зловживань.

Аналіз останніх досліджень і публікацій. Проаналізовано публікації представників української доктрини податкового права пов'язаної 3 даною проблематикою: Сахно Д.С., МузикаСтефранчук О.А., Ямненко Т.М., Винницкий Д.В., Жигаленко О., Івасенко С., Дроговоз Ю., Дубровський В. та інших.
Результати аналізу наукових джерел дозволили визначити механізми протизаконних дій податкових органів податків а також окреслити перспективи запобігання порушенням законодавства податковими органами.

Виділення не вирішених раніше частин загальної проблеми. Не дивлячись на те, що на даний момент існують публікації по тематиці зловживань правом у сфрері оподаткування податковими органами, жодна 3 них не розглядає цієї проблематики в такому комплексному баченні, залучаючи детальну класифікацію типів недобросовісних дій податкових органів.

Формулювання цілей статті. Головною метою цієї статті $є$ дослідження проблематики зловживань правом у сфері оподаткування податковими органами та окреслення перспектив 
запобігання порушенням законодавства податковими органами.

Виклад основного матеріалу. Виконуючи свій обов'язок перед державою зі сплати податків платники неминуче стикаються 3 податковими органами, які покликані не лише контролювати повноту їх нарахування та сплати, але й надавати сервісні послуги платникам. Проте, не завжди дії посадових осіб контролюючих органів здійснюються в межах правового поля. А їх прагнення понад усе забезпечити збір податків до бюджету, поряд із законними методами, доволі часто супроводжується й протизаконними. У свою чергу і платники податків защікавлені у залишенні у власному розпорядженні якомога більшої суми грошових коштів, занижуючи свої податкові зобов'язання перед бюджетами або затягуючи їх сплату. Коли платники податків обирають такий варіант власної поведінки у податкових відносинах, то вони починають зловживати своїми правами у оподаткуванні [1, с. 89].

Отже, цей процес не однобічний, адже спостерігається взаємозумовленість зловживань правом у сфрері оподаткування, коли зловживання своїми правами 3 боку одних учасників податкових правовідносин тягнуть появу неправомірного інтересу інших учасників, що фрактично спонукає їх до поширення явища зловживання податковими правами в тих конкретних податкових відносинах, учасниками яких вони $€[2$, c. 121]. У доктрині та податковому законодавстві деяких країн для оцінки добросовісності дій суб'єктів податкових правовідносин активно використовуеться поняття «зловживання правом», що розуміється як результат певних діянь, вчинених $з$ метою повного або часткового звільнення від податку [3, с. 40].

Відповідно до концепції зловживання правом у податкових відносинах найчастіше поєднують зловживання 3 недобросовісною поведінкою та відрізняють два типи недобросовісних дій у сфрері оподаткування:

1) зловживання суб'єктивними правами, що випливають iз положень приватного права, спрямоване на обхід приписів податкового права - притаманне платникам податків, які не виконують приписів податкового законодавства;

2) зловживання безпосередньо суб'єктивними податковими правами - таке зловживання притаманне податковим органам [4, с. 269; 5, с. 59-64].

Характерним є те, що зловживання правом у досліджуваних відносинах характеризується збереженням зовнішньої форми дій і поведінки їх учасників як правомірної й цілком законослухняної з підміною їх внутрішнього змісту, дійсної мети й фрактичного інтересу, що в цей момент переслідуються. Така мета й інтерес перетинають межу правомірної й дозволеної законом поведінки і стають у конфронтащію з головними цілями правового регулювання податкових відносин.

Водночас, саме службові особи податкових органів, які дозволяють собі зловживати своїми правами у відносинах 3 платниками податків $\epsilon$, так би мовити, «нульовою» детермінантою зазначеної взаємозумовленості, адже вони є представниками держави, яка покликана дотримувати права свого суспільства. Першоджерело зловживань своїми правами й повноваженнями
3 боку контролюючих органів міститься саме в тому змісті й у тих можливостях використання владних повноважень, які закладаються законодавцем у загальнорегулятивні податково-правові норми, що й визначають мету, цілі, сутність та особливості загальнорегулятивних податкових правовідносин [6, с. 123]. У ст. 17 Конвенції про захист прав людини і основоположних свобод [7] зловживання правом визначається як діяльність або дії, спрямовані на скасування прав та свобод, визнаних у Конвенщії, або на їх обмеження в більшому обсязі, ніж це передбачено в Конвенції. При цьому Суд Свропейського Союзу вказав, що податкові зловживання не є правопорушеннями, бо формально усі вимоги закону дотримані.

Слід погодитись, що сутнісна причина неправомірної поведінки органів, які мають бути неупередженими й об'єктивними в реалізації наданих їм владних повноважень, криється в переважанні користі й упевненості в тому, що вони можуть отримати певний зиск від задоволення неправомірних інтересів при зловживанні їх правами, над потенційними негативними наслідками такого зловживання, тим більше враховуючи те, що виявити й довести фракт зловживання своїми повноваженнями при розгляді податкового спору в межах охоронних податкових правовідносин доволі складно, а іноді й майже неможливо [8, с. 147].

Доречно наголосити, що службові особи, зловживаючи у відносинах з платниками податків, не виконують свої обов'язки, закріплені у ст. 21 ПК України, зокрема: дотримуватися Конституції України та діяти виключно у відповідності з ПК України, іншими законами України та іншими нормативними актами, забезпечувати едективну роботу та виконання завдань контролюючих органів відповідно до їх повноважень, не допускати порушень прав та охоронюваних законом інтересів платників податків, коректно та уважно ставитися до платників податків, їх представників та інших учасників податкових правовідносин тощо.

Зловживання податковими органами в правовідносинах 3 платниками податків можна класифікувати за зовнішнім проявом такого діяння на:

- пов'язані з обрахуванням та сплатою платником податків обов'язкових платежів, а також отриманням бюджетного відшкодування;

- пов’язані з реалізацією контрольної фрункції;

- пов'язані із забезпеченням податкових надходжень.

Для першої групи зазначених зловживань притаманні можливості податкового органу, що пов'язані з їх повноваженнями щодо визначення розміру податків, що мусять сплатити платники, а також розміру пені та штрафів.

До зазначеної групи відноситься маніпулювання даними, отриманими під час перевірки заявленого відшкодування 3 податку на додану вартість, метою яких є затягування здійснення цього відшкодування і змушення платника податків витрачати ресурси на процедури оскарження рішень, прийнятих податковим органом. Податковий орган зацікавлений у тому, щоб сума бюджетного відшкодування не набула статусу узгодженої та не виникло зобов'язання $з$ їі 
відшкодування або таке відшкодування відбулось у меншому розмірі, аніж могло б бути.

Також зловживання можливі під час визначення правильності податкових зобов'язань, розрахованих платником податків. У цьому випадку податковий орган навмисно не бере до уваги витрати суб'єкта господарювання, що зменшують базу оподаткування 3 податку на прибуток підприемств і дають підстави для формування податкового кредиту з податку на додану вартість. Підставами для неврахування витрат може бути будь-що: це й відомості про відсутність партнера в ланцюгу постачання товару за юридичною адресою, певні дефекти в його правовому статусі, відомості про відсутність у нього виробничих i технічних можливостей на здійснення певних операцій тощо. Таким чином створюються умови для збільшення надходжень до бюджетів за рахунок донарахування сум податкових зобов'язань тим платникам, які мають право на їх зменшення. Сприяе цьому недосконалість юридичної техніки, використаної при закріпленні податкового законодавства.

Зазначені вище зловживання стають можливими у тому числі внаслідок недосконалості законодавства. Адже діяльність податкового органу врегульована не лише нормами ПК України, але й внутрішніми організащійно-розпорядчими документами обмеженого доступу, які значно розширюють їх права та іноді прямо суперечать вимогам чинного законодавства. Зокрема, такими організащійно-розпорядчими документами $є$ наказ ДФС України від 28.07.2015 р. № 543 «Про забезпечення комплексного контролю податкових ризиків з ПДВ» [9], Методичні рекомендації щодо організації та проведення органами державної фріскальної служби зустрічних звірок, обміну податковою інформацією при здійсненні податкового контролю [10]. Кожен з цих наказів встановлює додаткові інструменти тиску на бізнес або додаткове обмеження прав платників податків.

Застосування механізмів, не передбачених Податковим кодексом України, зазвичай як показуе практика, проти сумлінних платників податків, не передбачає чітких процедур захисту та поновлення останніми своїх прав, що дає службовим особам податкового органу необмежені можливості для корупції. Зокрема, запровадження системи електронного адміністрування ПДВ супроводжуеться побудовою в програмному забезпеченні на підставі технічних завдань певних алгоритмів, які в більшості випадків не передбачені нормами ПК України або прямо суперечать їм, що дозволяе керувати такою системою в ручному закритому режимі.

Націленість податкової системи на виконання індикативних показників 3 надходження до бюджету, відсутність відповідальності за корупційні діяння, можливість для службових осіб діяти поза межами ПК України, користуючись лише внутрішніми наказами та розпорядженнями вищестоящого органу або особистими сумнівними мотивами, доводить необхідність або дуже детально описувати всі процедури з встановлення прав та обов'язків платників податків та податкового органу з можливістю справедливого захисту таких прав в судах (що не буде мати ефректу на практиці з недосконалою судовою системою та свавіллям державних службовців), або змінювати фрілософрію взаємовідносин між платниками податків і контролюючими органами через зміну цілей, фрункцій, системи оцінки діяльності податкового органу, а також більш активного притягнення до відповідальності службових осіб податкового органу за свої дії або бездіяльність.

До другої групи зловживань також входить низка діянь, що певним чином обмежують права платника податків. Серед цих зловживань розповсюдженими є такі, що пов'язані з направленням податковим органом запитів до платника податків з вимогою про надання інформації. Відповідно до ст. 20 ПК України, податковий орган має право вимагати від платника податків надання інформації, у тому числі первинної бухгалтерської документації. Проте, йдеться про запити, оформлені в межах перевірки фрактів, що свідчать про порушення податкового законодавства, про надання відомостей, які є джерелом інформації [11]. Водночас, податковий орган, зловживаючи своїм правом на направлення письмового запиту платникові податків, у низці випадків надсилає такий запит без відповідної правової підстави. При цьому зловживання повноваженнями виявляеться у формі незазначення в тексті письмового запиту про надання пояснень, документів і відомостей, що послужили джерелом інформації, а також конкретних фрактів, що свідчать про порушення податкового законодавства. Розширенню даної фрорми зловживань сприяе визначення обов'язку платника податків під час перевірки надавати пояснення та їх документальне підтвердження на запит податкового органу, що часто виявляеться у вимозі надавати такі документи по всім операціям за період, що перевіряеться, незважаючи на те, що підтверджуючі документи платником податків надаються тільки по виявленим порушенням.

Також у цій групі доцільно окреслити зловживання, пов'язані 3 безпідставним призначенням податковим органом перевірки платника податків. Зазначені діяння знайшли свій прояв у різних формах. Зокрема, призначення документальної позапланової виїзної перевірки платника податків за результатами відповіді на письмовий запит контролюючого органу, який не містить жодних конкретних підстав для його надіслання, та за відсутності конкретних фрактів, що свідчили б про порушення платником податків податкового законодавства. Тобто призна-

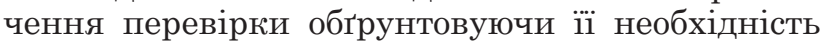
припущеннями щодо нереального здійснення господарських операщій. Протиправність такого діяння визнана Верховним Судом України, який наголошуе, що для призначення i проведення контролюючим органом документальної позапланової невиїзної перевірки платника податків обов'язковим $є$ дотримання встановлених у ПК України вимог, що стосуються підстав перевірки, спрямованих на гарантування дотримання прав платників податків, звуження підстав для проведення перевірки контролюючим органом, усунення можливостей зловживання ним своїм правом на перевірку $[12 ; 13]$.

Іншою формою зловживань при призначенні документальної позапланової перевірки платника податків $є$ викривлення сутності умови щодо 
направлення йому письмового запиту і наголошення на фрактах порушення ним податкового законодавства. За цих обставин, зловживаючи своїм правом, податковий орган указує лише на фракт, начебто, наявності в нього інформащії, що свідчить про порушення податкового законодавства платником податків, проте не розкриваючи, яке саме порушення вчинено останнім. Варіаці$є ю$ цього зловживання $є$ наголошення податковим органом на виявлених порушеннях податкового законодавства у взаємовідносинах платника 3 його контрагентом та намагання витребувати документальне підтвердження операцій по цих взаємовідносинах. Отже, податковий орган призначае перевірку на підставі, начебто, наявних неузгоджень і порушень податкового законодавства, проте без визначення відповідних підстав для цьог, закріплених ПК України [14, с. 148].

Наступною фрормою зловживань податковим органом в ході реалізації контрольної фрункції $€$ вихід за межі предмета перевірки, що призводить до визнання будь-яких наслідків останньої як позбавлених правових підстав. I хоча право податкового органу виходить 3 його фрункціонального призначення і є одним із прав, закріплених у ст. 20 ПК України, кожен з видів перевірок, передбачених у податковому законодавстві, має свій предмет, за який податковий орган не має виходити. Тому доказом виходу за межі предмету перевірки є власне акт такої перевірки, здобутий з порушенням податкового законодавства, що тягне за собою визнання перевірки незаконною як і відсутність іï правових наслідків. Це обумовлюе неправомірність прийнятих на його підставі податкових повідомлень-рішень [15]. Наведену тезу підтверджуе рішення Верховного Суду України, відповідно до якого податковий орган не мав повноважень досліджувати під час проведення одного з видів перевірок - камеральної, питання своєчасності сплати податків, оскільки на час існування спірних правовідносин зазначене питання перебувало поза межами цієї перевірки й були предметом лише перевірки документальної [16].

Також зловживання при призначенні перевірок вчиняються у випадку, коли податковий орган безпідставно вдається до розширеного тлумачення норм податкового законодавства, які регулюють інститут податкових перевірок. Що виражається у виході за межі підстав останніх, у застосуванні зі зворотною силою податковоправових норм, які погіршують правове становище платника податків, чим порушуються його законні права й інтереси. Розширене тлумачення норм податкового законодавства можливе як умисно, так і ненавмисно. Остання ситуація стає можливою внаслідок не завжди високої кваліфікації службових осіб податкового органу, недостатності роз'яснень вищестоящих органів щодо особливостей застосування податкового законодавства, а також у випадку переслідування квазіпублічних інтересів для збільшення показників діяльності конкретних територіальних підрозділів податкових органів.

Окремо привертає увагу зловживання, пов'язані з оформленням акту за результатами перевірки. Існуючи сьогодні затверджені нормативні форми документальної перевірки за змістом $є$ лише переліком формальних показників діяльності платника податків без аналітичних висновків і майже без упровадження фрактичних методів контролю [17, с. 134]. Амордність, невизначеність форм і методів податкового контролю дозволяють службовій особі податкового органу особисто вирішувати, що включати в акт перевірки, а що - ні. Саме така службова особа за результатами перевірки вирішуе, як скласти акт перевірки [18, с. 242] i, власне від цього буде залежати, до якої відповідальності (фінансової, адміністративної або кримінальної) бути притягнута особа у разі виявлення в ході перевірки порушень податкового законодавства. Непоодинокі випадки коли при складанні актів перевірок службовою особою податкового органу запозичуються фрормулювання 3 інших актів перевірок в аналогічних ситуаціях, не надається належна і об'єктивна правова оцінка конкретним господарським i фінансовим операціям або ж навмисно невірно трактуються фрактичні обставини справи та певні фракти представляються у протилежному світлі. Ще однією формою зловживань, пов'язаних з оформленням акту перевірки, $€$ рішення службової особи податкового органу не передавати такий документ, який містить інформацію щодо вчиненого правопорушення, до відповідного правоохоронного органу, а сприяти його затримці або взагалі знищенню.

Отже, група зловживань, пов'язаних з реалізацією контрольних фрункцій, містить низку діянь, зокрема, зловживання при направленні письмового запиту платникові податків і незазначення в тексті письмового запиту про надання пояснень, документів і відомостей, які є джерелом інформації, й конкретних фрактів, що свідчать про порушення цим платником податкового законодавства, зловживання у формі виходу за межі предмета податкової перевірки, а також зловживання у формі зміни мотивів прийнятих контролюючим органом індивідуальних рішень, що змінюють стан суб'єктивних прав та обов'язків. При цьому зазначені форми зловживань податкового органу можуть як існувати окремо один від одного, так і об'єднуватись у рамках конкретних податкових правовідносин, завдаючи тим самим більшу шкоду податковим відносинам. При цьому можливими $є$ й інші види і прояви зловживань, оскільки теоретично кожне окремо надане право контролюючому органу можна використати всупереч його призначенню й цілям податково-правового регулювання [19, с. 187].

Ще одна форма зловживань правом з боку податкових органів - правом на забезпечення сплати податкового боргу 3 використанням такого засобу, як адміністративний арешт активів платника податків та подальший їх продаж підконтрольним структурам. Адміністративний арешт полягає в забороні здійснювати платником податків будь-які дії щодо своїх активів, які підлягають такому арешту, крім дій з їх охорони, зберігання й підтримання в належному фрункціональному і якісному стані. Він являе собою винятковий спосіб забезпечення виконання платником податків його обов'язків, визначених законом, у тому числі забезпечення можливості погашення податкового боргу платника податків. I хоча в законодавстві передбачено обов'язковість узгодження дій податкового органу із судовими органами при на- 
кладанні адміністративного арешту на рахунки платника податків, яке здійснюеться виключно на підставі рішення суду шляхом звернення до нього податкового органу (пп. 20.1.15 п. 20.1 ст. 20 ПК України), можливість зловживання правом з боку останнього не виключається. Зокрема, активи, які перебувають у податковій заставі, можуть бути продані за заниженими цінами, тобто виторг від їх реалізації буде недостатнім для погашення всіх податкових зобов'язань платника податків. Наслідком таких дій може бути сприяння окремих службових осіб податкового органу в отриманні платником податків свого майна, яке було реалізоване з метою погашення податкових зобов'язань перед державою [20, с. 242].

Крім того, доцільним є виокремити групу зловживань, пов'язаних з автоматизацією податкових правовідносин. При цьому привертає увагу, що умови для зловживання податковим органом, в окремих випадках, створюються законодавцем. Зокрема, з 2015 року було запроваджено систему електронного адміністрування, яка поставила у пряму залежність право на податковий кредит від умови обов'язкової реєстрації податкових накладних в Сдиному реєстрі податкових накладних. Це призвело до застосування інструментарію, не передбаченого нормами чинного законодавства, а встановленого лише внутрішніми наказами органів ДФС України (зокрема, через присвоєння платникам податків певних станів (особливо 9 «Направлено повідомлення за фр. № 18-ОПП» та 8 «У ЄДР внесено запис про відсутність за місцезнаходженням»). На підставі присвоєння цих станів податкові органи блокують реєстрацію податкових накладних та подання електронної звітності, що практично спонукає платників припиняти свою діяльність до моменту розблокування реєстрації податкових накладних або подання електронної звітності.

Крім того, поява практики блокування податковим органом реєстращії податкових накладних та подання електронної звітності обмежуе право контрагентів таких платників на податковий кредит. Зокрема, податковий орган неодноразово знаходить приводи відмовити у подачі таблиці даних платника податків щоразу під новим надуманим приводом, а саме: через нібито невідповідність виду діяльності в таблиці даних та наявним основним засобам, через нібито наявну в органах ДПС України податкової інформації, що свідчить про здійснення платником податків ризикових операцій, а інколи навіть під приводом «інше». Такі випадки не поодинокі, це доволі поширене явище, яке блокує фрактично роботу низки компаній. Тобто податковий орган отримав дуже потужний інструмент корупційного впливу на платників податків та, в окремих випадках, механізм штучного збільшення платежів до бюджету. Отже, ще однією формою прояву зловживань 3 боку податкового органу $є$ блокування податкових накладних, що створює штучні перепони для своєчасного відшкодування ПДВ та перетворює бізнес експортера на неприбутковий. А також вимагання "відкату» або сплати наперед податку на прибуток як плати за відшкодування ПДВ.

Також запровадження системи електронного адміністрування ПДВ супроводжуеться побудовою в програмному забезпеченні на підставі технічних завдань певних алгоритмів, які в більшості випадків не передбачені нормами ПК України або прямо суперечать їм, що дозволяє керувати такою системою в ручному закритому режимі [21, с. 13]. Або ж несвоєчасна реєстрація низки податкових накладних через протиправне розірвання податковим органом договору про визнання електронних документів.

Ще однією фрормою зловживань службовою особою податкового органу є втручання в роботу інформаційно-телекомунікаційних систем ДПС України. Зокрема, маніпулящії 3 інформацією, яка в них зберігається і обробляеться, призводить до витоку, підробки, блокування даних, спотворення процесу обробки інформації та порушення встановленого порядку іiї маршрутизації. При цьому спотворення даних в базах ITC «Податковий блок», ITC «Електронний кабінет», ITC «Сдине вікно подання електронної звітності», «Сдиного реєстру податкових накладних", системі моніторингу відповідності податкових накладних розрахунків коригування критеріям оцінки ступеня ризиків "СМКОР» дозволило підприемствам, що обслуговуються конвертаційно-транзитними групами, ухилятись від сплати податків.

Висновки і пропозиції. Таким чином, зловживання посадовими особами податкових органів своїми повноваженнями полягає в недобросовісному їх здійсненні й заподіянні шкоди правам і законним інтересам платників податків. 3-поміж іншого цьому сприяе нечіткість приписів чинного податкового законодавства та неоднозначна судова практика 3 проблемних питань. Радикальні зміни у вищезазначених copepax матимуть позитивний вплив на запобігання порушенням законодавства податковими органами.

\section{Список літератури:}

1. Сахно Д.С. Публічний інтерес у податкових відносинах та чинники, що загрожують його реалізації. Право та інноваційне суспільство. 2017. № 2(9). С. 87-91.

2. Сахно Д.С. Зловживання правом у податкових правовідносинах : дис. ... канд. юрид. наук : 12.00 .07 / ДВНЗ «Університет державної фіскальної служби України». Ірпінь, 2019. С. 121.

3. Музика-Стефанчук О.А. Термінологічні проблеми податкового законодавства в контексті вітчизняної та европейської судової практики. Наука і правоохорона. 2017. № 2(36). С. 37-46.

4. Ямненко Т.М. Здійснення прав у фінансових правовідносинах: проблеми зловживання та доказування неправомірної поведінки : дис. ... докт. юрид. наук : 12.00.07 / ДВНЗ «НАУ». Київ, 2016. С. 269.

5. Винницкий Д.В. Принцип добросовестности и злоупотребление правом в сфере налогообложения. Право $u$ эконолика. 2003. № 1. С. 59-64.

6. Сахно Д.С. Зловживання правом у податкових правовідносинах : дис. ... канд. юрид. наук. Спеціальність 12.00.07 - адміністративне право і процес; фінансове право; інформаційне право. Ірпінь, 2019. 248 с.

7. Конвенція про захист прав людини i основоположних свобод від 04 листопада 1950 p. URL: https://zakon.rada.gov.ua/laws/show/995_004\#Text (дата звернення: 20.07.2021). 
8. Сахно Д.С. Зловживання правом у податкових правовідносинах : дис. ... канд. юрид. наук. Спеціальність 12.00.07 - адміністративне право і процес; фрінансове право; інформаційне право. Ірпінь, 2019. 248 с.

9. Про забезпечення комплексного контролю податкових ризиків з ПДВ : Наказ Державної фріскальної служби України від 28 лип. 2015 р. № 543. URL: https://ips.ligazakon.net/document/DFS01105 (дата звернення: 20.07.2021).

10. Про затвердження Методичних рекомендацій щодо організації та проведення органами державної фріскальної служби зустрічних звірок, обміну податковою інформацією при здійсненні податкового контролю : Наказ Державної фріскальної служби України від 17 лип. 2015 р. № 511. URL: https://ips.ligazakon.net/document/ view/DFS01322 (дата звернення: 20.07.2021).

11. Постанова Верховного Суду України у складі колегії суддів Касаційного адміністративного суду від 7 лютого 2019 р. за справою № 813/2716/17; адміністративне провадження № K/9901/28565/18. URL: www.reyestr.court.gov.ua/ Review/79671346 (дата звернення: 20.07.2021).

12. Постанова Верховного Суду України у складі колегії суддів Касащійного адміністративного суду від 7 лютого 2019 р. за справою № 813/2716/17; адміністративне провадження № K/9901/28565/18. URL: www.reyestr.court.gov.ua/ Review/79671346 (дата звернення: 20.07.2021).

13. Постанова Верховного Суду України у складі колегії суддів Касаційного адміністративного суду від 29 серпня 2018 р. за справою № 820/2541/15; адміністративне провадження № K/9901/8114/18. URL: www.reyestr.court.gov.ua/ Review/7616553 (дата звернення: 20.07.2021).

14. Сахно Д.С. Зловживання правом у податкових правовідносинах : дис. ... канд. юрид. наук. Спеціальність 12.00.07 - адміністративне право і процес; фрінансове право; інформаційне право. Ірпінь, 2019. С. 148.

15. Постанова Верховного Суду України у складі колегії суддів Касащійного адміністративного суду від 15 червня 2018 р. за справою № 817/98/16; адміністративне провадження № K/9901/19536/18. URL: www.reyestr.court.gov.ua/ Review/74718270 (дата звернення: 20.07.2021).

16. Постанова Верховного Суду України у складі колегії суддів Касаційного адміністративного суду від 14 червня 2018 р. за справою № 812/1028/17; адміністративне провадження № K/9901/685/17. URL: www.reyestr.court.gov.ua/ Review/74718201 (дата звернення: 20.07.2021).

17. Жигаленко О. Совершенствование методических основ документального налогового контроля. Підприєлництво, господарство і право. 2007. № 4. С. 134.

18. Івасенко С. Запобігання корупційним ризикам у податкових органах України. Державне управління та лісиеве саловрядування. 2015. Вип. 1(24). С. 238-245.

19. Сахно Д.С. Зловживання правом у податкових правовідносинах : дис. ... канд. юрид. наук. Спеціальність 12.00.07 - адміністративне право і процес; фінансове право; інформаційне право. Ірпінь, 2019. 248 с.

20. Івасенко С. Запобігання корупційним ризикам у податкових органах України. Державне управління та лісцеве самоврядування. 2015. Вип. 1(24). С. 238-245.

21. Дроговоз Ю., Дубровський В. Інституційні проблеми української податкової системи та шляхи їх вирішення. Аналітична розробка. Київ, 2015. С. 13.

\section{References:}

1. Sakhno D.S. (2017) Publichnyy interes u podatkovykh vidnosynakh ta chynnykakh, shcho zahrozhuyut' yoho realizatsiyi [Public interest in tax relations and factors threatening its implementation]. Pravo ta innovatsiyne suspil'stvo - Law and innovation society, no. 2(9), pp. 87-91.

2. Sakhno D.S. (2019) Zlovzhyvannya pravom u podatkovykh pravovidnosynakh [Abuse of rights in tax relations]. Candidate's thesis. Irpin': DVNZ „Universytet derzhavnoi fiskalnoi sluzhby Ukrainy”.

3. Muzyka-Stefanchuk O.A. (2017) Terminolohichni problemy podatkovoho zakonodavstva u konteksti vitchyznyanoyi ta yevropeys'koyi sudovosti [Terminological problems of tax legislation in the context of domestic and European case law]. Nauka i pravookhorona - Science and law enforcement, no. 2(36), pp. 37-46.

4. Yamnenko T.M. (2016) Zdiysnennya prav u finansovykh pravovidnosynakh: problemy zlovzhyvannya ta dokazuvannya nepravomirnoyi diyal'nosti [Exercise of rights in financial relations: problems of abuse and proof of misconduct]. Extended abstract of Doctor's thesis. Kyiv: DVNZ „Natsionalnyi Aviatsiinyi Universytet”.

5. Vynnytskyy D.V. (2003) Pryntsyp dobrovil'nosti ta zlovzhyvannya pravom u sferi nalohoobrobky [The principle of good faith and abuse of law in the field of taxation]. Pravo i ekonomika-Law and Economics, no. 1, pp. 59-64. (in Russian)

6. Sakhno D.S. (2019). Zlovzhyvannya pravom u podatkovykh pravovidnosynakh [Abuse of rights in tax relations]. Candidate's thesis. Irpin': DVNZ „Universytet derzhavnoi fiskalnoi sluzhby Ukrainy”.

7. Konventsiya pro zakhyst prav lyudyny ta osnovopolozhnykh svobod vid 04 lystopada 1950 r. [Convention for the Protection of Human Rights and Fundamental Freedoms of November 4, 1950]. Retrieved from: https://zakon.rada.gov.ua/laws/show/995_004\#Text (accessed July 20, 2021).

8. Sakhno D.S. (2019) Zlovzhyvannya pravom u podatkovykh pravovidnosynakh [Abuse of rights in tax relations]. Candidate's thesis. Irpin': DVNZ „Universytet derzhavnoi fiskalnoi sluzhby Ukrainy”.

9. Pro zabezpechennya kompleksnoho kontrolyu podatkovykh ryzykiv z PDV: Nakaz Derzhavnoyi fizykal'nzhiyi slukhovoyi fizykal'nzhsyi khirurhiyi. 2015 r. № 543 [On ensuring comprehensive control of VAT tax risks: Order of the State Fiscal Service of Ukraine of July 28. 2015 № 543]. Retrieved from: https://ips.ligazakon.net/document/ DFS01105 (accessed July 20, 2021).

10. Pro zatverdzhennya Metodychnykh rekomendatsiy shchodo orhanizatsiyi ta provedennya orhaniv derzhavnoyi fiskal'noyi sluzhby zustrichnykh zvirok, zmenshennya podatkovoyi informatsiyi pry zdiysnenni podatkovoho kontrolyu: Zayava Derzhavnoyi fiskal'noyi sluzhby Ukrayiny vid 17 lypnya 2015 r. № 511 [About the statement of Methodical recommendations concerning the organization and carrying out by bodies of the state fiscal service of counter reconciliations, an exchange of the tax information at implementation of tax control: the Order of the State fiscal service of Ukraine from July 17. 2015 № 511]. Retrieved from: https://ips.ligazakon.net/document/ view/DFS01322 (accessed July 20, 2021).

11. Postanova Verkhovnoho Sudu Ukrayiny v skladi kolehiyi sudiv Kasatsiynoho administratyvnoho sudu viho za spravoyu № 813/2716/17; administratyvne provadzhennya № K/9901/28565/18 [Resolution of the Supreme Court of Ukraine in the composition of the panel of judges of the Administrative Court of Cassation of February 7, 2019 in case № 813/2716/17; administrative proceedings № K/9901/28565/18]. Retrieved from: www.reyestr.court. gov.ua/Review/79671346 (accessed July 20, 2021). 
12. Postanova Verkhovnoho Sudu Ukrayiny u skladi kolehiyi sudiv Kasatsiynoho administratyvnoho sudu za spravoyu № 813/2716/17; administratyvne provadzhennya № K/9901/28565/18 [Resolution of the Supreme Court of Ukraine in the composition of the panel of judges of the Administrative Court of Cassation of February 7, 2019 in case № 813/2716/17; administrative proceedings № K/9901/28565/18]. Retrieved from: www.reyestr.court.gov.ua/ Review/79671346 (accessed July 20, 2021).

13. Postanova Verkhovnoho Sudu Ukrayiny u skladi kolehiyi sudiv Kasatsiynoho administratyvnoho sudu Sudu Serindu v. za spravoyu № 820/2541/15; administratyvne provadzhennya № K/9901/8114/18 [Resolution of the Supreme Court of Ukraine in the composition of the panel of judges of the Administrative Court of Cassation of August 29, 2018 in case № 820/2541/15; administrative proceedings № K/9901/8114/18]. Retrieved from: www.reyestr.court.gov.ua/Review/7616553 (accessed July 20, 2021).

14. Sakhno D.S. (2019) Zlovzhyvannya pravom u podatkovykh pravovidnosynakh [Abuse of rights in tax relations]. Candidate's thesis. Irpin': DVNZ „Universytet derzhavnoi fiskalnoi sluzhby Ukrainy”.

15. Postanova Verkhovnoho Sudu Ukrayiny u skladi kolehiyi sudiv Kasatsiynoho administratyvnoho sudu vid 15 chervnia 2018 r. za spravoyu № 817/98/16; administratyvne provadzhennya № K/9901/19536/18 [Resolution of the Supreme Court of Ukraine in the composition of the panel of judges of the Administrative Court of Cassation of June 15, 2018 in case № 817/98/16; administrative proceedings № K/9901/19536/18]. Retrieved from: www.reyestr.court.gov.ua/Review/74718270 (accessed July 20, 2021).

16. Postanova Verkhovnoho Sudu Ukrayiny u skladi kolehiyi sudiv Kasatsiynoho administratyvnoho sudu sudu Cheridu. za spravoyu № 812/1028/17; administratyvne provadzhennya № K/9901/685/17 [Resolution of the Supreme Court of Ukraine in the composition of the panel of judges of the Administrative Court of Cassation of June 14, 2018 in case № 812/1028/17; administrative proceedings № K/9901/685/17]. Retrieved from: www.reyestr.court.gov.ua/Review/74718201 (accessed July 20, 2021).

17. Zhyhalenko O. (2007) Sovershenstvovanye metodycheskykh osnov dokumental'noho novoho naukovoho kontrolyu [Improving the methodological foundations of documentary tax control]. Pidpryyemstvo, hospodarstvo ta pravo Entrepreneurship, economy and law, no. 4, p. 134. (in Russian)

18. Ivasenko S. (2015) Zapobihannya koruptsiynym ryzykam u podatkovykh orhanakh Ukrayiny [Prevention of corruption risks in the tax authorities of Ukraine]. Derzhavne upravlinnya ta mistse samovryaduvannya-Public administration and local self-government, vol. 1(24), pp. 238-245.

19. Sakhno D.S. (2019) Zlovzhyvannya pravom u podatkovykh pravovidnosynakh [Abuse of rights in tax relations]. Candidate's thesis. Irpin': DVNZ „Universytet derzhavnoi fiskalnoi sluzhby Ukrainy”.

20. Ivasenko S. (2015) Zapobihannya koruptsiynym ryzykam u podatkovykh orhanakh Ukrayiny [Prevention of corruption risks in the tax authorities of Ukraine]. Derzhavne upravlinnya ta mistse samovryaduvannya-Public administration and local self-government, vol. 1(24), pp. 238-245.

21. Drohovoz Yu., Dubrovs'kyy V. (2015) Instytutsiyni problemy ukrayins'koyi podatkovoyi systemy ta shlyakhy yikh vyrishennya [Institutional problems of the Ukrainian tax system and ways to solve them]. Analitychna rozrobka. Kyiv. 